\title{
THE STATE OF BIO-ECOLOGICAL CHARACTERISTICS OF THE ONE-YEAR SHOOTS OF Robinia pseudoacacia L. UNDER THE CONDITIONS OF INDUSTRIAL POLLUTION
}

\author{
TETIANA YUSYPIVA, HALYNA MIASOID
}

Department of Physiology and Introduction of Plants, Oles Honchar Dnipro National University, Gagarin Ave., 72, Dnipro, 49010, Ukraine; e-mail: JusypivaTatjana@i.ua

Department of International Tourism, Hotel and Restaurant Business and Language Training, Alfred Nobel University, 18, Sicheslavska Naberezhna Str., Dnipro, 49055, Ukraine; e-mail: galyna.miasoid@gmail.com

\begin{abstract}
Yusypiva T., Miasoid H.: The state of bio-ecological characteristics of the one-year shoot of Robinia pseudoacacia L. under the conditions of industrial pollution. Ekológia (Bratislava), Vol. 38, No. 3, p. $240-252,2019$.

The paper studies the influence of industrial pollution on bio-ecological characteristics of the oneyear shoot of Robinia pseudoacacia L. in the conditions of the city of Dnipro, Ukraine. It analyses the state of biometric parameters of the shoot and anatomic indices of the stem of the studied species exposed to toxic gases. It was found that there are adaptive changes in the histological structure of the stem of $R$. pseudoacacia under the conditions of technogenesis. The study revealed that bio-ecological characteristics of the black locust are highly resistant to industrial emissions with big shares of $\mathrm{SO}_{2}$ and $\mathrm{NO}_{2}$. It was suggested to use R. pseudoacacia for greening of the technogenic territories.
\end{abstract}

Key words: anatomical indices, biometric parameters, toxic gases, greening, bioindication.

\section{Introduction}

The problem of environmental protection and rehabilitation is not losing its relevance in the 21 century. One of the most serious consequences of anthropogenic impact on the natural environment is pollution of atmospheric air, soil and water by man-made emissions that causes the reduction of biodiversity (Kozak, Didukh, 2014). Even such balanced ecosystems as forests change significantly as a result of technogenesis (Baciak et al., 2015; Masternak et al., 2015), and in many anthropogenic cases, the transformation of forest biogeocenoses leads to their degradation and the inability to perform ecological functions (Voron, 2011; Matkovskaya, Klymchyk, 2016).

However, it is the creation of artificial green spaces in the field of the impact of industrial waste and vehicle exhaust components that can significantly improve the environmental situation when properly selected for the planting of ornamental trees and shrubs (Levon, 2008; 
Zhang et al., 2013; Nikolić et al., 2017). The main requirements for tree-bush species are good absorption capacity, resistance to certain classes of pollutants prevailing in the ecotopes of the planting area, and a wide range of adaptive reactions, from biochemical and anatomicalmorphological to genetic ones, which allow maintaining at an appropriate level both the ontogenesis and the reproductive ability of individual components of phytocenosis, and the ability of the entire forest range to self-regulate, self-renew and self-reproduce (Levon, 2003; Kucheriavyj, 2005).

The study of tree species and shrubs also seeks to find sensitive bio-ecological indicators of the vegetative and generative spheres of a separate plant organism and tree stands in general, which can be used to diagnose plant conditions in megacities and industrial agglomerations (Hnativ, 2014; Grytsay, Miasoid, 2016) and set ecological norms of anthropogenic loads on forest ecosystems (Voron, 2011).

The response of the plant to the action of negative environmental stress factors can be determined by the appearance of plants and the changes in their morphometric indices (Ivanchenko, Bessonova, 2016). In addition to the intensity of vegetative growth and plant condition, the indices of the anatomical structure of the shoots are taken into account for the integral assessment of the viability and the promise of the technogenic introduction of treebush breeds as the processes of their formation are a structural reflection of the physiological and biochemical mechanisms of plant growth (Brajon, Chikalenko, 1992; Beck, 2005).

It is known that aerotechnogenic factors of the environment cause both functional and structural changes in tissues and organs (Arsenyeva, Chavchavadze, 2001; Albrechtova, 2003); therefore, stem histological characteristics can serve as informative criteria for monitoring anthropogenic environmental transformation (Kurteva, Stambolieva, 2007).

Taking into account all of the above, the purpose of the work is to analyse the state of bioecological characteristics of the one-year shoots of Robinia pseudoacacia L. in the conditions of industrial pollution of the city of Dnipro (Ukraine).

\section{Material and methods}

\section{Study area}

Dnipropetrovsk region is one of the most polluted areas in Ukraine, with high level of urbanization and concentration of industrial enterprises and highways. The forest cover of the region is $5.6 \%$ (General characteristics of forests of Ukraine, 2016); most of the forests are artificial and perform mainly sanitary, hygienic and protective functions. Dnipro is a powerful multi-industrial centre of Ukraine (The City of Dnipropetrovsk, Amending the general plan of the city development, 2015), which has four major industrial regions: Western, Left-bank, Southern and Eastern. The most contaminated areas are the Western and the Southern areas, the latter includes the CJSC 'Plant Dnipropres' (hereinafter 'Dnipropres') (Yemets, Serdyuk, 2003).

The chronic effect of aerotechnogenic loading is exacerbated by extreme climatic conditions, like hot summer with drylands, dry and frosty winter with frequent temperature fluctuations, strong winds, as well as soil-hydrological conditions, like frequent and prolonged droughts, which complicates the normal existence of the forest in the Dnipropetrovsk region (Zaitseva, Dolgova, 2010), located in the zone of the Northern steppe of Ukraine.

\section{Monitoring points}

The plant materials were selected in September 2011 in two sites. The test area is located in the artificial forest plantation, located along the highways at a distance of $2 \mathrm{~km}$ from the source of industrial emissions, Dnipropres, Dnipro 
$\left(48^{\circ} 38^{\prime} 00.8^{\prime \prime} \mathrm{N}, 35^{\circ} 00^{\prime} 17.5^{\prime \prime} \mathrm{E}\right)$, where the concentrations of $\mathrm{SO}_{2}$ and $\mathrm{NO}_{2}$ were 5.8 and 6 maximum permissible values accordingly (Peremetchik, Polischuk, 2011; Striletz et al., 2013). The relatively clean reference area is located in the village of Pryadivka of Tsarychanka area in Dnipropetrovsk region (48 $89^{\prime} 81.3^{\prime \prime} \mathrm{N}, 34^{\circ} 70^{\prime} 16.9^{\prime \prime}$ E), where the concentrations of sulphur (IV) and nitrogen (IV) oxides do not exceed the maximum permitted values $\left(\mathrm{SO}_{2}-0.05\right.$ $\mathrm{mg} / \mathrm{m}^{3}, \mathrm{NO}_{2}-0.04 \mathrm{mg} / \mathrm{m}^{3}$ ) (Striletz et al., 2013). The forest conditions, the characteristics of the tree stand, the structure and composition of plantations in the test area and in the reference area were similar.

\section{Plant material}

The research object is the introduced tree species of black locust, or false acacia, $-R$. pseudoacacia L. (genus Fabaceae Lindl.). The species is widely grown in the steppe and forest-steppe zones, as it occupies an important place in amenity planting and phytomelioration. The widespread use of $R$. pseudoacacia for sylvatization in the steppe can be explained by its relatively rapid growth (Grimal'skij, 1951; Strojnaja, 1991), a small number of pests and diseases (Voloshyn, 1994), drought-and-wind resistance, and also by its ability to grow in very dry places (Zverkovskyy et al., 2018), including the steep slopes.

The samples of $R$. pseudoacacia one-year shoots in each of the test areas were taken from the southeast side of the crown of five model trees of the same age at a height of $1.7 \mathrm{~m}$ from the soil level. As bio-ecological indicators, the morphometric and anatomical characteristics of the shoots were studied. Biometric measurements were made in 100 -fold repeat according to the generally accepted methods (Zlobin et al., 2009), after which the stems of 30 shoots were fixed in $96 \%$ alcohol. Cross sections of the stem were made at a distance of $2 \mathrm{~cm}$ from the stem base with the help of a manual microtome and stained with phloroglucinol (Albrechtova, 2003). The preparations were examined under a light microscope BRESSER Biolux LCD 40x-1600x and the thickness of the tissues was measured at 100fold increase, the diameter of the vessels - at 400 -fold increase in a 30 -fold repetition.

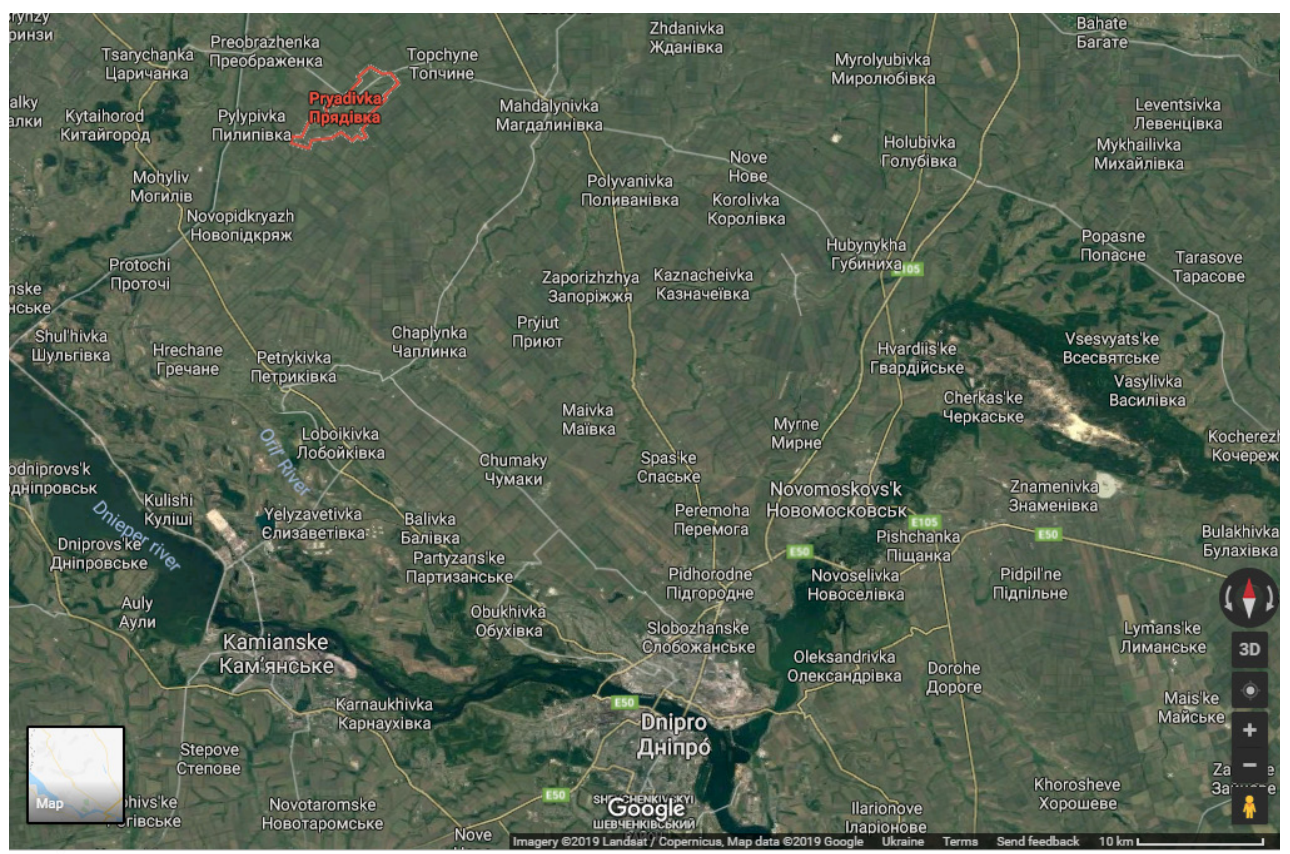

Fig. 1. The map of Dnipropetrovsk region and the sites of monitoring points. https://www.google.com.ua/maps/@4 $8.7208385,34.6968211,10 \mathrm{z}$ hl=en 


\section{Statistical analysis}

The results of the study were handled using a multifunctional application software package STATGRAFICS. Mean absolute error was calculated. To compare the biometric characteristics of annual shoots and the stem anatomical parameters of reference and test samples we used Student's t-test $(\mathrm{p}<0.05)$. Normality allocation of the sample had been preliminarily assessed.

\section{Results and discussion}

The state of biometric indices of the one-year shoots of Robinia pseudoacacia L. under conditions of industrial pollution

The research shows the ambiguous effect of industrial pollution of $\mathrm{SO}_{2}$ and $\mathrm{NO}_{2}$ on the biometric characteristics of the one-year shoots of $R$. pseudoacacia, in which the value of the part of the shoot morphometric indices decreases significantly compared with the reference one, whereas some other characteristics increase.

As can be seen from Table 1, the annual shoot growth of the R. pseudoacacia shoot under conditions of industrial pollution increases substantially compared with this indicator in the plants of the relatively clean zone and amounts to $146.5 \%$ of the control value. Probably, the stimulating effect of industrial emissions on the growth of shoots in technogenic zones can be explained by the increased content of nitrogen-containing compounds in industrial soil, as they can be a source of plant root nutrition (Korshykov, 1996).

Zverev (2008) showed a significant extension of the Betula pubescens subsp. czerepanovii (Orlova) Hämet-Ahti, which undergoes chronic emissions of $\mathrm{SO}_{2}$ by nickel-copper smelter at Monchegorsk. Annual growth of the shoot of Spirea L. species representatives in the conditions of industrial pollution by $\mathrm{SO}_{2}, \mathrm{NO}_{\mathrm{x}}$ and heavy metals was $102-181 \%$ of the values of this index in the plants of the relatively clean area (Chernikova, 2009). Hryshko (2002) established an increase in the length of the shoots of Ulmus pumilla L., Robinia pseudoacacia, Populus canadensis Moench. due to the increase in the length of the internodes and their number; although Aesculus hippocastanum L. demonstrates a decrease in these parameters, which leads to a decrease in the length of the shoots in the plants of this species. However, Yakovleva-Nosar' (2017) found a significant decrease of the annual shoot growth of Robinia pseudoacacia shoots in the urboecosystem with a high level of technogenic loading.

$\mathrm{T}$ a b l e 1. The influence of industrial pollution on biometric indicators of annual shoots of Robinia pseudoacacia $(\mathrm{M} \pm \mathrm{m}, \mathrm{n}=100)$.

\begin{tabular}{|l|c|c|}
\hline Indicator & Control & Industrial area \\
\hline Annual shoot growth, cm & $7.07 \pm 1.13$ & $10.36 \pm 1.22^{*}$ \\
\hline Number of leaves produced on 1 year of growth shoot, items & $6.57 \pm 0.79$ & $6.61 \pm 1.32$ \\
\hline Number of leaves on the model branch, items & $92.93 \pm 5.99$ & $63.80 \pm 2.44^{*}$ \\
\hline Number of leaflets in a model compound leaf, items & $14.60 \pm 2.16$ & $13.77 \pm 1.06$ \\
\hline Area of one model leaflet, $\mathrm{cm}^{2}$ & $7.66 \pm 0.11$ & $9.61 \pm 0.26^{*}$ \\
\hline Area of one model leaf, $\mathrm{cm}^{2}$ & $112.34 \pm 10.29$ & $135.97 \pm 3.13^{*}$ \\
\hline The area of the assimilating surface on the model branch, $\mathrm{cm}^{2}$ & $10435.29 \pm 43.06$ & $8679.37 \pm 61.44^{*}$ \\
\hline
\end{tabular}

Note: ${ }^{\star}$ - differ significantly from control $(\mathrm{p}<0.05)$. 
The state of growth and development of vegetative plant organs can be estimated using the biometric characteristics of the assimilation apparatus. Changes in the size of individual leaves and the leaf surface are generally associated with changes in the intensity of photosynthesis in the plant organism. The area of the assimilation surface in the studied tree species depends on a number of biometric characteristics of the shoots, namely, the number of leaves on the model branch, the area of the model leaf, which, in turn, depends on the other two parameters, the number of leaflets in the compound leaf and the area of the model leaflet, since the leaves of $R$. pseudoacacia are compound.

We found, the numbers of leaves produced in the one year shoots in the reference and test trees are almost the same, with insignificant difference between reference and test samples at $\mathrm{p}<0.05$ (Table 1). However, as the annual shoot growth is higher under the conditions of pollution, the number of leaves on the model branch (calculated per $1.0 \mathrm{~m}$ length) in the plants in the industrial site is significantly lower as compared with the relatively clean area and make $68.7 \%$ of the reference value. The number of leaflets in a compound leaf is a more constant value, probably programmed at the genetic level, and the study did not find the differences between the values of this index in plants in different growth conditions.

Regarding the area of the model leaf in R. pseudoacacia, there was a significant increase in the value of this parameter in plants in the sanitary protection zone around the CJSC 'Plant Dnipropres' (21.0\% compared to the reference one), due to a significant increase in their area of the model leaflet by $25.5 \%$ compared to the reference value. When the leaf surface was studied, it was ascertained that this parameter in the research object decreases by $16.8 \%$ of this value in plants from the relatively clean area, which makes a significant change in the conditions of technogenesis. Despite the fact that the area of $R$. pseudoacacia model leaf increases significantly when exposed to the industrial emissions of $\mathrm{SO}_{2}$ and $\mathrm{NO}_{2}$, the value of the assimilation surface area goes down due to the slower number of compound leaves than in the reference area.

It should be noted, that the previous scholars have found that industrial emissions can both stimulate and inhibit the growth and development of leaves depending on the species of tree and shrub plants. Thus, the area of assimilation surface in the decorative shrubs increases under the influence of $\mathrm{SO}_{2}$ and $\mathrm{NO}_{2}$ toxic gases; the highest, compared with the control value, was the area of the leaf surface in Ptelea trifoliata L., and it grew in Caragana arborescens Lam. and Cornus sanguinea (L.) Opiz (Iusypiva, Minejeva, 2010). Kolmogorova (2013) found a decrease in the number of leaves on the annual shoots, the area and mass of leaves Syringa vulgaris L., Betula pendula Roth. and Sorbus sibirica Hedl., since they were exposed to the heavy car emissions in the city of Kemerovo. In the conditions of multicomponent pollution of $\mathrm{SO}_{2}, \mathrm{NO}_{2}$ and heavy metals, the area of the model leaf decreased significantly in $B$. pendula plants, but due to their bigger amounts, the area of the assimilation surface increased (Iusypiva, Zamorena, 2011). Yakovleva-Nosar (2017) has established a significant decrease in the leaf area of Robinia pseudoacacia exposed to the emissions of motor vehicles and metallurgical enterprises.

Parpan and Mylenka (2009) noted the decrease in the area of leaf plates and the growth of dichromatic and necrotic damages of leaves because of the industrial emissions near TPP. Krupenko and Kapelush (2014) revealed an increase in the fluctuating asymmetry of leaves 
and a decrease in the number of leaf plates in the plants of Tilia cordata Mill. in the conditions of the chronic action of the components of industrial emissions and emissions of vehicles in the city of Zaporizhzhia, as well as the representatives of Betula pendula in the city of Kryvyi Rih (Savosko, Katolichenko, 2014).

The previous research also found that near the highways in the city of Dnipro (Ponomaryova, Bessonova, 2009), environmental pollution causes a decrease in the morphometric indices of the assimilation apparatus Tilia cordata and T. platyphyllos Scop. compared to the reference value. In the conditions of urban parks in the city of Yaroslavl, it was ascertained that as concentrations of pollutants in the atmospheric air increase, leaf growth is suppressed and the number and degree of their necrotic damage to Betula pendula, Tilia cordata and Populus nigra L. increase (Marakaev et al., 2006).

Thus, the study of the influence of industrial emissions produced by 'Dnipropres' on the morphometric characteristics of Robinia pseudoacacia one-year shoots showed that the growth processes in plants of this species are suppressed in the conditions of technogenesis. In particular, the number of leaves on the model branch and the area of the assimilation surface decrease significantly, although three indicators increase. They are the annual shoot growth, the area of the model leaflet and the area of the model leaf. We view these reactions of $R$. pseudoacacia trees to the stress caused by industrial pollution as adaptive mechanisms of compensatory type.

The state of the anatomical indices of Robinia pseudoacacia L. one-year shoots under the conditions of industrial pollution

The study of the influence of 'Dnipropres' emissions on the state of the anatomical indices of R. pseudoacacia one-year shoot stem revealed their high sensitivity to the chronic effects of aerogenic pollutants (Tables 2,3, Figs 2,3). As can be seen from Table 2, in the conditions of chronic exposure to sulphur dioxide and nitrogen, the thickness of the primary cortex of the stem of the research object decreases by $11.9 \%$ compared with the reference value. This is due to a decrease in the size of such histological elements of the primary cortex as cork (phellem) and cortex parenchyma.

Phellem is an outer layer of the primary cortex, so it protects the underlying tissues from the stress caused by environmental factors. In plants growing in conditions of industrial pollution, the thickness of this tissue at the shoot base decreases by $11.8 \%$, when compared to

$\mathrm{T} \mathrm{a} \mathrm{b} \mathrm{le} \mathrm{2.} \mathrm{The} \mathrm{effect} \mathrm{of} \mathrm{industrial} \mathrm{pollution} \mathrm{on} \mathrm{the} \mathrm{thickness} \mathrm{of} \mathrm{the} \mathrm{primary} \mathrm{cortex} \mathrm{tissues} \mathrm{of} \mathrm{the} \mathrm{one-year} \mathrm{shoot} \mathrm{stem}$ of Robinia pseudoacacia, $\mu \mathrm{m}(\mathrm{M} \pm \mathrm{m}, \mathrm{n}=30)$.

\begin{tabular}{|l|c|c|c|}
\hline Indicator & Control & Industrial area & \% of the reference value \\
\hline Cork Thickness & $66.31 \pm 1.49$ & $58.47 \pm 2.35^{\star}$ & 88.2 \\
\hline Collenchyme Thickness & $60.91 \pm 2.97$ & $57.88 \pm 1.35$ & 95.0 \\
\hline Primary Cortex Parenchyma Thickness & $17.03 \pm 0.49$ & $12.16 \pm 0.05^{\star}$ & 71.4 \\
\hline Primary Cortex Thickness & $144.27 \pm 8.07$ & $127.02 \pm 3.46^{*}$ & 88.0 \\
\hline
\end{tabular}

Note: ${ }^{*}$ - differ significantly from control $(\mathrm{p}<0.05)$. 
the reference values. Due to the protective functions of the cork - like it does not infiltrate gases and liquids, protects against water loss and overheating and other adverse environmental factors (Brajon, Chikalenko, 1992; Beck, 2005) - reducing the cork thickness in technogenic conditions can reduce the resistance of $R$. pseudoacacia to toxic gases and negative impacts of climatic factors.

Collenchyma, that is, the mechanical tissue of the primary cortex of $R$. pseudoacacia stem is lamellar and placed under the cork in 3-5 rows. The analysis of Table 2 shows that the thickness of this histological part of the black locust stem in the technogenic environment is unchanged, with the insignificant differences between the reference and test samples at $\mathrm{p}$ $<0.05$. The thickness of the parenchyma, which is located under the collenchyma and is an intrinsic layer of the primary cortex of the $R$. pseudoacacia stem, changes most significantly. It drops by $28.6 \%$ among the histological elements of the primary cortex of the stem in the shoot base.

It should be noted that the thickness of the primary cortex of the stems of woody and shrub plants can either increase or decrease depending on the type of plants, conditions of their growth, as well as the type and extent of the influence of anthropogenic environmental factors. Thus, Leppik and Bocharov (2007) found a decrease in the periderm thickness in the Catalpa bignonioides Walt. stems, which grew in the area of exhaust emissions. Nuzhyna et al. (2014) discovered that the number of collenchyma layers increased with the increase of the levels of technogenic loading on Rosa centifolia L., $R$. rugosa Thunb., R. xanthina Lindl, although the index of collenchyma thickness compared to the control values went up only in $R$. rugosa representatives. The authors explain this phenomenon as the protective

a)

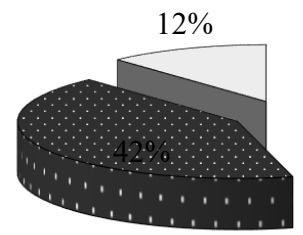

b)
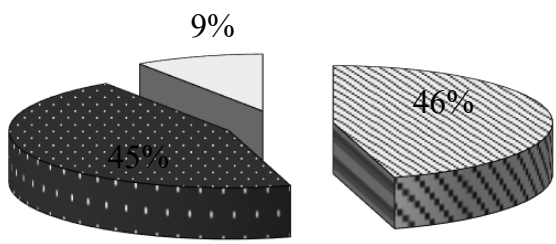

๑Cork $\square$ Collenchyme

$\square$ Primary Cortex Parenchyma

Fig. 2. The influence of $\mathrm{SO}_{2}$ and $\mathrm{NO}_{2}$ on the ratio of histological elements of primary cortex of annual shoot stems of Robinia pseudoacacia, \%: a) - Control (reference area), b) - test area. reaction of the plant organism to the increasing effect of the irritant agents. The previous research showed that moderate doses of toxic substances stimulate the thickening of cork parenchyma more intensively in $R$. centifolia and $R$. rugosa, whereas severe contamination inhibits the development of this tissue.

Bessonova and Kryvoruchko (2017) showed that in the shoots of Quercus rubra L. plants growing in roadside plantation, there was an increase of the cork and collenchyma thickness indices, 4 radial rows of cells in the reference area, 6 rows in the test area, which according to the authors, ensures better protection of internal tissues from the penetration of pollutants.

To analyse the effect of industrial emissions on the process of forming the external protective tissues of the stem, it is necessary to learn the thickness of the constituent parts of the cortex not only in absolute but also in 
relative values, that is, the proportion of each tissue in percentage as a share of the overall width of the shoot primary cortex. The analysis of Fig. 2 shows that due to the industrial emissions of Dnipropres, there are changes in the ratio of the histological elements of the primary cortex in the stems of Robinia pseudoacacia. Thus, the cork share remains unchanged, the thickness of collenchyma is increasing in the total volume of the cortex, and the share of parenchyma is decreasing by a quarter in comparison with the clean area.

The central cylinder (stele) of $R$. pseudoacacia stem consists of secondary cortex (phloem), wood (xylem), medullary sheath and pith (Table 3). It should be noted, that the phloem histological structure in the research object is specific; its hard bast forms a solid ring of strongly lignified bast fibres in the soft bast.

The analysis of the thickness of the histological elements of this part of the stele indicates that the chronic exposure of $R$. pseudoacacia plants to industrial pollution with the predominance of $\mathrm{SO}_{2}$ and $\mathrm{NO}_{2}$ leads to changes in its formation. Thus, the width of the bast fibre layer reduces by $18.2 \%$ under technogenic conditions compared with the control value (Table 3 ), while the thickness of the conductive elements of the secondary cortex and bast parenchyma increases by $11.9 \%$ relative to the size of the soft bast in the plants of black locust that grow in a relatively clean zone. We noted that under the influence of industrial phytotoxic pollutants on the studied plants, the changes in the radii of the phloem constituents are mutually compensatory, that is, they do not cause the changes in the width of the secondary cortex of $R$. pseudoacacia shoots stem base, with insignificant differences between the reference and the test samples at $\mathrm{p}<0.05$.

Bast formation is important for the normal functioning of the transport system in plants; it contributes to the creation of the donor-acceptor relations of the plant organism, which provides the outflow of photosynthesis products from the assimilation organs to other organs. As it stimulates the photosynthesis process, the soft bast volume growth in the conditions of technogenesis can increase plant productivity.

The literature analysis confirms the sensitivity of structural elements of trees and shrubs phloem to the action of negative biotic, abiotic and anthropogenic environmental factors. Thus, Abdussalam et al. (2015) recorded a complete damage to the secondary phloem in the

$\mathrm{T}$ a b le 3. The influence of industrial pollution on the size of the stele histological elements of Robinia pseudoacacia one-year shoots, $\mu \mathrm{m}(\mathrm{M} \pm \mathrm{m}, \mathrm{n}=30)$.

\begin{tabular}{|l|c|c|c|}
\hline Indicator & Control & Industrial area & \% of the reference value \\
\hline Hard Bast Thickness & $111.12 \pm 3.25$ & $124.34 \pm 2.61^{*}$ & 111.9 \\
\hline Soft Bast Thickness & $59.14 \pm 1.92$ & $48.39 \pm 4.86^{*}$ & 81.8 \\
\hline Secondary Cortex Thickness & $170.26 \pm 16.13$ & $174.74 \pm 26.49$ & 102.6 \\
\hline Wood Radius & $284.96 \pm 24.20$ & $288.99 \pm 44.82$ & 101.4 \\
\hline The Largest Vessel Diameter & $48.39 \pm 10.20$ & $47.18 \pm 5.75$ & 97.5 \\
\hline Medullary sheath Radius & $84.23 \pm 8.83$ & $78.63 \pm 5.99$ & 93.4 \\
\hline Pith Diameter & $913.14 \pm 77.23$ & $662.67 \pm 48.15^{*}$ & 72.6 \\
\hline Stem Diameter & $2283.81 \pm 90.02$ & $2159.95 \pm 67.94$ & 94.6 \\
\hline
\end{tabular}

Note: ${ }^{*}$ - differ significantly from control $(\mathrm{p}<0.05)$. 
stems of Boerhavia diffusa L. under the influence of heavy metals of cadmium, chromium and copper. Yusypiva and Rudenko (2009) found an increase of soft bast thickness in oneyear shootings of Ulmus pumilla L. when exposed to $\mathrm{SO}_{2}$ and $\mathrm{NO}_{2}$ toxic gases. Under the conditions of urbocenosis, the thickness of the stem secondary cortex in Acer negundo L. and $A$. platanoides L. was almost unchanged in comparison to the values in the reference area; however, it increased by 25\% in A. pseudoplatanus L. species (Pavlyukova, Legostayeva, 2016).

Xylem is an area of the central cylinder of the stem, located deep in the secondary cortex. It provides transport of water and mineral nutrients in plant, and it is the main supporting part of the stem (Brajon, Chikalenko, 1992; Beck, 2005). The structure of the wood and medullary sheath in Robinia pseudoacacia has certain features. Xylem looks like a solid ring formed by vessels of almost identical diameter. Medullary sheath in the form of a ring with uneven edges covers a pith that takes the form of a star.

In the conditions of industrial emissions of $\mathrm{SO}_{2}$ and $\mathrm{NO}_{2}$ (Table 3), the radius of xylem almost does not change compared with the value of this index in plants of a relatively pure zone; the differences between reference and test samples are insignificant at $p<0.05$. The same can be concluded about the diameter of the vessels: the size of the largest of the tested vessels in $R$. pseudoacacia shoots is similar in value to the ones in the reference zone.

It should be noted that a large number of species of tree plants respond to industrial pollution by decreasing their vessel diameter and vessel wall thickness (Kaakinen et al., 2004; Mahmooduzzafar et al., 2010), the wood thickness (Griztay, Shupranova, 2015) and the annual rings diameter (Whitmore, Freer-Smith, 1982).

Therefore, the stability of these histological characteristics of the research object under exposure of chronic toxic gas impact testifies to the relative stability of $R$. pseudoacacia to the studied pollutants. That makes it possible to state that the anthropogenic introduction of the investigated tree species into the regions of the steppe Prydniprovya with priority pollution of $\mathrm{SO}_{2}$ and $\mathrm{NO}_{2}$ has been successful.

The pith of $R$. pseudoacacia stem consists of large diameter cells that perform a storage function. The reduction of this area of the stem central cylinder is significant and makes $27.4 \%$ compared with the reference value in the conditions of technogenesis. At the same time, the medullary sheath radius remains almost unchanged, at the insignificant differences between reference and test samples at $\mathrm{p}<0.05$. Since significant deviations in the thickness of the histological elements of the annual shoot stem stele of the investigated tree species were not found under the technogenic growth conditions, there are no significant changes in the stem diameter of $R$. pseudoacacia in the industrial site (Table 3).

The considerable amount of data obtained during laboratory and field experiments indicates the negative influence of toxic compounds on the growth of stems of woody and shrub plants (Whitmore, Freer-Smith, 1982; Kaakinen et al., 2004; Griztay, Shupranova, 2015, etc.) Thus, the long-term effects of high concentrations of $\mathrm{CO}_{2}$ and $\mathrm{O}_{3}$ reduced the distance between the stem pith and its cortex in Populus tremuloides (Kaakinen et al., 2004).

Table 3 presents data in micrometres. To analyse the effect of industrial emissions on the tissue formation of the stem central cylinder, we calculated the share of each tissue in percentages relative to the total width of the shoot stele, that is, the value of histological parameters in absolute values (Fig. 3). 
It was found that the emissions of Dnipropres cause changes in the ratio of the components of Robinia pseudoacacia central cylinder; there is a significant increase of wood share compared to the indices of plants from the clean area, a less significant increase of the soft bast share and a significant decrease of the pith share. As for the shares of the hard bast and medullary sheath, their values in the test and reference areas are relatively similar.

In our previous study (Iusypiva, Miasoid, 2017), we found an increase in the shares of the hard bast and medullary sheath relative to the total volume of the stem stele in the undergrowth of Acer platanoides and Fraxinus excelsior, which increased when they were constantly exposed to sulphur and nitrogen dioxides in comparison with the values in the reference area. Notably, in the stems of the former species, the shares of the soft bark, wood and pith of the stem stele volume did not change in comparison with the control values, while in the latter species, the shares of the hard bast and medullary sheath increased, whereas the share of wood diminished.

Thus, the examination of the impact of industrial emissions with priority pollutants of $\mathrm{SO}_{2}$ and $\mathrm{NO}_{2}$ on the anatomical characteristics of the stem of Robinia pseudoacacia annual shoots showed that there are adaptive changes in the formation of histological elements of the stele under conditions of technogenesis in the plants of the species under study. This becomes evident in the fact that the shares of the transport tissues, soft bast and xylem, and the mechanical tissues, like collenchyma increase due to the decrease of parenchymal tissue of the stem (the pith and parenchyma of the primary cortex). Shcherbinina (2004) documented an increase of parenchymal tissues' shares in the representatives of Betula pubescens Ehrh. and Tilia cordata, which grew along the highway.

\section{Conclusion}

Technogenic pollution of the environment with sulphur and nitrogen dioxides leads to a change in the growth intensity of Robinia pseudoacacia aboveground vegetative organs. The 
values of some growth indicators, such as the number of leaves on the model branch, the area of the leaf surface goes down under technogenic conditions, while others increase, like the values of the annual shoot growth, the area of the model leaflet, the area of the model compound leaf.

It is ascertained that when the plants of R. pseudoacacia undergo the chronic exposure to $\mathrm{SO}_{2}$ and $\mathrm{NO}_{2}$ industrial emissions, the thickness of the cork and cork parenchyma decrease, which, in turn, causes the thinning of the primary cortex.

In technogenic conditions of plant growth, the secondary cortex thickness does not change significantly due to the compensation of the decrease of the hard bast width by increasing the soft bast thickness.

The pith diameter reduces due to the impact of phytotoxicants, while the wood and medullary sheath almost do not change with respect to the reference values. The stem diameter of the annual shoots of $R$. pseudoacacia plants growing in the area exposed to industrial phytotoxicants does not differ significantly from the stem diameter of the plants in the relatively clean area.

The conducted research proves that the bio-ecological characteristics of one-year shoots of $R$. pseudoacacia are highly resistant to industrial emissions with predominance of sulphur and nitrogen dioxides; therefore, we propose to use this tree species in the landscaping of man-made territories contaminated with $\mathrm{SO}_{2}$ and $\mathrm{NO}_{2}$.

\section{References}

Abdussalam, A.K., Ravindran, C.P., Ratheesh Chandra, P., Azeez, K. \& Nabeesa S. (2015). Physiological effects of heavy metal toxicity and associated histological changes in Boerhavia diffusa L. Journal of Global Biosciences, 4(1), 1221-1234. http://mutagens.co.in

Albrechtova, J. (2003). Plant Anatomy in Environmental Studies. Prague: Charles University in Prague. http:// kfrserver.natur.cuni.cz/lide/albrecht/pdf/2003_Albrechtova_Habilitation_Plant_Anatomy_Environment.pdf

Arsenyeva, T.V. \& Chavchavadze E.S. (2001). Ecological and anatomical aspects of Pinaceae wood variability in the Industrial Areas of European North (in Russian). St. Petrsburg: Nauka Publ.

Baciak, M., Warmiński, K. \& Bęś A. (2015). The effect of selected gaseous air pollutants on woody plants. Forest Research Papers, 76(4), 401-409. DOI: 10.1515/frp-2015-0039.

Beck, C.B. (2005). An introduction to plant structure and development. Plant anatomy for the twenty first century. Cambridge: Cambridge University Press.

Bessonova, V.P. \& Kryvoruchko A.P. (2017). Changes in the structural indices of annual shoots of Quercus rubra under anthropogenic impact (in Ukrainian). Biosystems Diversity, 25(3), 191-196. DOI: 10.15421/011729.

Brajon, O.V. \& Chikalenko, V.G. (1992). Plant anatomy (in Ukrainian). Kyiv: Vyscha Shkola Publ.

Chernikova, O.V. (2009). Ecology-biological indicators of Spiraea L. genera plant resistance in the technogenic conditions of Steppe Pridneprove (within Dnipropetrovsk) (in Ukrainian). Dissertation for degree of Candidate of Biological Sciences in Ecology, Dnipropetrovsk.

General characteristics of forests of Ukraine (2016) // http://dklg.kmu.gov.ua/forest/control/uk/publish/article?art_ id=62921\&cat_id=32867

Grimal'skij, V.I. (1951). Black locust in the steppe afforestation of the Ukrainian SSR (in Ukrainian). Dissertation for degree of Candidate of Biological Sciences in Ecology, Kyiv.

Griztay, Z.V. \& Shupranova L.V. (2015). Impact of emissions of Pridneprovsk TPP in Dnipropetrovsk on the anatomical indices of stem of two-year whip of the Tilia genus representatives (in Ukrainian). Biosystems Diversity, 23(2), 230-235. DOI: 10.15421/011534.

Grytsay, Z. \& Miasoid G. (2016). Assessment of floral organs state of Tilia genus representatives under environment pollution conditions caused by emissions of Prydniprovska Thermal Power Plant, Dnipropetrovsk city. International Letters of Natural Sciences, 55, 52-56. DOI: 10.18052/www.scipress.com/ILNS.55.52. 
Hnativ, P.S. (2014). Functional diagnostic of dendroecology: Scientific monograph (in Ukrainian). L'viv: Prospect 'Kamula'.

Hryshko, V.N. (2002). Growth of woody plants in conditions of man-made pollution (in Ukrainian). Ukr. Bot. Zh., 59(1), 79-89.

https:/www.google.com.ua/maps/@48.7208385,34.6968211,10z?hl=en

Ivanchenko, O.E. \& Bessonova V.P. (2016). Indication of the condition of woody plants of parks in Dnipropetrovsk on morpho-physiological indexes (in Ukrainian). Biosystems Diversity, 24(1), 109-118. DOI: 10.15421/011613.

Iusypiva, T.I. \& Minejeva K.J. (2010). Biometric characteristics of a one-year shoots of decorative shrubs in the conditions of man-made territories (in Ukrainian). In News about modern science - 2010. $6^{\text {th }}$ International scientific and practical conference, 17-25 May 2010 (pp. 57-61). Sofia: Publishing House 'Education and Science'.

Iusypiva, T.I. \& Zamorena V.S. (2011). Changes of biometric parameters of Betula pendula Roth. one-year sprouts under technogenesis conditions (in Russian). In Future questions from the world of science -2011 . $7^{\text {th }}$ International scientific and practical conference, 17-25 December 2011 (pp. 23-25). Sofia: Publishing House "Education and Science".

Iusypiva, T. \& Miasoid G. (2017). The Impact of Industrial Pollution on the Stem Anatomical Characteristics of Woody Plant Undergrowth in the City of Dnipro, Ukraine. International Letters of Natural Sciences, 65, 1-9. DOI: 10.18052/www.scipress.com/ILNS.65.1.

Kaakinen, S., Kostiainen, K., Ek, F., Saranpaa, P., Kubiske, M., Sober, J., Karnosky, D.F. \& Vapaavuori E. (2004). Stem wood properties of Populus tremuloides, Betula papyrifera and Acer saccharum saplings after 3 years of treatments to elevated carbon dioxide and ozone. Global Change Biology, 10, 1513-1525. DOI: 10.1111/j.13652486.2004.00814.X.

Kolmogorova, E.Y. (2013). The morphometric characteristic of the wood plants growing in the conditions of impact of vehicle emissions (in Russian). Zhivye i Biokosnye Sistemy, 4. http://www.jbks.ru/archive/issue-4/article-6

Kozak, O. \& Didukh Y. (2014). Assessment of mountain ecosystems changes under anthropogenic pressure in Latorica river basin (Transcarpathian region, Ukraine). Ekológia (Bratislava), 33(4), 365-379. DOI: 10.2478/eko-2014-0033.

Korshykov, I.I. (1996). Adaptation of plants to the conditions of technologically polluted environment (in Russian). Kyiv: Naukova dumka Publ.

Krupenko, L.S. \& Kapelush N.V. (2014). Condition of assimilation system Tilia cordata under aerogenic pollution in Zaporozhye city. Problems of Bioindicators and Ecology, 19(2), 84-90.

Kucheriavyj, V.P. (2005). Planting of settlements: a textbook (in Ukrainian). L'viv: Svit Publ.

Kurteva, M. \& Stambolieva K. (2007). Acer pseudoplatanus L., Acer platanoides L. and Betula pendula (Roth.) as bioindicators of urban pollution in Sofia. Silva Balcanica, 8(1), 32-46.

Leppik, M.V. \& Bocharov O.M. (2007). Influence of motor vehicle emissions on the anatomical structure of one-year shoots of Catalpa bignonioides Walt (in Ukrainian). In Modern issues of plant physiology and plant introduction: All-Ukrainian scientific and practical conference, 22-23 May 2007 (p. 80). D.: DNU Press.

Levon, F.M. (2003). Creation of green plantings in conditions of the urbanized environment: the requirements limiting factors, ways of optimization. Scientific Bulletin of UNFU, 13(5), 157-162.

Levon, F.M. (2008). Green areas in anthropogenically transformed medium: Monograph (in Ukrainian). Kyiv: NNC IAE.

Mahmooduzzafar, S.S., Hegazy, I.M. A. \& Iqbal M. (2010). Anatomical changes in the wood of Syzygium cumini exposed to coal-smoke pollution. Journal of Food, Agriculture \& Environment, 8, 959-964. DOI: $10.1234 / 4.2010 .3475$.

Marakaev, O.A., Smirnova, N.S. \& Zagoskina N.V. (2006). Technogenic stress and its effect on deciduous trees (an example from parks in Yaroslavl) (in Russian). Russian Journal of Ecology, 37(6), 373-377.

Masternak, K., Niebrzydowska, B. \& Głebovska K. (2015). Genetic variation of silver fir (Abies alba Mill.) preserved in the Katowice Forest District. Forest Research Papers, 76(4), 315-321. DOI: 10.1515/frp-2015-0030.

Matkovskaya, S.I. \& Klymchyk O.N. (2016). Environmental role of representatives of the genus Picea in the city green plants of Zhytomyr (in Ukrainian). Scientific Bulletin of UNFU, 26(8), 210-215. DOI:10.15421/40260833.

Nikolić, N., Zorić, L., Cvetković, I., Pajević, S., Borišev, M., Orlović, S. \& Pilipović A. (2017). Assessment of cadmium tolerance and phytoextraction ability in young Populus deltoides L. and Populus $\times$ euramericana plants through morpho-anatomical and physiological responses to growth in cadmium enriched soil. iForest - Biogeosciences and Forestry, 10, 635-644. DOI: 10.3832/ifor2165-010.

Nuzhyna, N.V., Tkachuk, O.O. \& Zuieva O.A. (2014). Adaptation peculiarities of wild roses to unfavorable environmental conditions (in Ukrainian). The Journal of V.N.Karazin Kharkiv National University. Series: Biology, 20(1100), 353-357. 
Parpan, V.I. \& Mylenka M.M. (2009). Morphophysiological characteristics of Populus pyramidalis Roz. under the conditions of urbanization and anthropogenic impact of the environment (in Ukrainian). Ecology and Noospherology, 20(3-4), 84-90.

Pavlyukova, N.F. \& Legostayeva T.V. (2016). Changes of anatomical and morphological indexes of Acer L. kin plants in the conditions of Dnipro city (in Ukrainian). Problems of Steppe Forest Science and Forest Land Reclamation, 45, 113-118.

Peremetchik, M.M. \& Polischuk S.Z. (2011). Building the map charts of atmospheric contamination to assist the system of ecological monitoring in the city of Dnipropetrovsk (in Ukrainian). http://www.eco.com.ua

Ponomaryova, O.A. \& Bessonova V.P. (2009). The influence of growth T. cordata and T. platyphyllos in hole into the asphalt of roadside zone of size the morphometric indicators of assimilation system (in Ukrainian). Problems of Bioindicators and Ecology, 14(2), 55-62.

Savosko, V.M. \& Katolichenko O.M. (2014). Fluctuating asymmetry of leave's silver birch in conditions of air pollution at Kryvorizhzhya. Problems of Bioindications and Ecology, 19(2), 90-102.

Shcherbinina, A.A. (2004). Display of abnormal growth of woody plants in the affected area of main highways. Dissertation for degree of Candidate of Biological Sciences in Ecology, Moscow.

Striletz, R.O. et al. (2013). Ecological passport of Dnipropetrovsk region (2013) (in Ukrainian). http://www.menr.gov. ua

Strojnaja, S.A. (1991). Protective afforestation on the irrigated lands of Ukraine and the North Caucasus (in Russian). Kyiv: Naukova dumka Publ.

The City of Dnipropetrovsk (2015). Amending the general plan of the city development (in Ukrainian). Kyiv.

Voloshyn, P.L. (1994). Black locust in cultures on the Right Bank area of the Central Steppe (in Ukrainian). Forestry Journal, $5,21$.

Voron, V.P. (2011). Scientific base of diagnostics of anthropogenic damage of forest ecosystems (in Ukrainian). Forestry Journal, 1, 24-28.

Whitmore, M.E. \& Freer-Smith P.H. (1982). Growth effects of $\mathrm{SO}_{2}$ and/or $\mathrm{NO}_{2}$ on woody plants and grasser during spring and summer. Nature, 300(5887), 55-57. DOI: 10.1038/300055a0.

Yakovleva-Nosar, S.O. (2017). Variability of morphometric parameters of vegetative and generative traits of Robinia pseudoacacia L. in areas with different levels of air pollution at Zaporizhzhya. Topical Issues in Biology, Ecology and Chemistry. 13(1), 16-26. https://sites.znu.edu.ua/bio-eco-chem-sci/issues/index.php?action=url/ view\&url_id=6749

Yemets, N.A. \& Serdyuk Ya.Ya. (2003). Assessment of the Dnepropetrovsk city territory regarding the level of air basin contamination (in Ukrainian). Ecology and Natural Resource Management, 6, 200-207.

Yusypiva, T. \& Rudenko E. (2009). Anatomy-morphological changes of shoots of Ulmus pumilla L. in conditions of industrial emissions of $\mathrm{SO}_{2}$ and $\mathrm{NO}_{2}$ (in Ukrainian). Bulletin Taras Shevchenko National University of Kyiv. Introduction and Conservation of Plant Diversity, 27, 164-166.

Zaitseva, I.O. \& Dolgova L.G. (2010). Physiological-biochemical basis of woody plants introduction in the steppe Prydniprovya. Dniproperovsk: Dnipropetrovsk National University Press.

Zhang, X., Zhou, P., Zhang, W., Zhang, W. \& Wang Y. (2013). Selection of landscape tree species of tolerant to sulfur dioxide pollution in subtropical China. Open Journal of Forestry, 3, 104-108. DOI: 10.4236/ojf.2013.34017.

Zlobin, Yu.A., Sklyar, V.G., Bondareva, L.M. \& Kyrylchuk K.S. (2009). The morphometric concept in modern botany. Chornomorski Botanical Journal, 5(1), 5-22.

Zverev, V. (2008). Impact of pollution and annual climatic fluctuations on growth of mountain birch. In Air pollution and climate change at contrasting altitude and latitude. $23^{\text {rd }}$ IUFRO Conference for Specialists in Air Pollution and Climate Change Effects on Forest Ecosystems, 7-12 Sept 2008 (pp. 94). Murten.

Zverkovskyy, V.M., Sytnyk, S.A., Lovynska, V.M., Kharytonov, M.M., Lakyda, I.P., Mykolenko, S.Yu., Pardini, G., Margui, E. \& Gispert M. (2018). Remediation potential of forest forming tree species within northern steppe reclamation stands. Ekológia (Bratislava), 37(1), 69-81. DOI: 10.2478/eko-2018-0007. 